Arq. Bras. Med. Vet. Zootec., v.69, n.2, p.278-284, 2017

\title{
Comparison of sexual performance and testicular characteristics of melatonin treated Kivircik and Charollais rams during the non-breeding season
}

\author{
[Comparação de desempenho reprodutivo e características testiculares de carneiros Kivircike \\ Charollais tratados com melatonina durante a estação não reprodutiva)

$$
\text { M. Cevik }{ }^{1} \text {, C. Yilmazer }{ }^{2} \text {, A. Kocyigit }{ }^{3}
$$ \\ ${ }^{1}$ Department of Reproduction and Artificial Insemination, Faculty of Veterinary \\ Medicine, Ondokuz Mayis University, 55200, Samsun, Turkey \\ ${ }^{2}$ Republic of Turkey Ministry of Food, Agriculture and Livestock, 59000, Tekirdag, Turkey \\ ${ }^{3}$ Department of Reproduction and Artificial Insemination, Faculty of Veterinary \\ Medicine, Cumhuriyet University, 58140, Sivas, Turkey
}

\begin{abstract}
This study was conducted to investigate the effects of melatonin implantation on basic testicular characteristics and reproductive performance of Kivircik and Charollais rams and ewes during the nonbreeding season. In this study, 8 Kivircik and 6 Charollais rams were used. Rams were implanted with 54 mg melatonin according to the manufacturer's instructions. At melatonin implantation and at ram introduction the reproductive performance and testicular characteristics were evaluated. Throughout the experimental period, rams were permanently kept outdoors under conditions of natural day length and at ambient temperature. The effects of exogenous melatonin treatments on the reproductive performances of rams and ewes, estrus response, pregnancy rate, litter size and twinning rate of ewes were evaluated in all groups. Libido values were significantly higher in Charollais rams compared to Kivircik rams $(\mathrm{P}<0.001)$. Testicular volume (TV) was increased in both ram breeds. Scrotal length (SL) was also increased in both Kivircik and Charollais rams $(\mathrm{P}<0.01)$. In conclusion, we showed that the treatment of rams with slow release melatonin implants increased scrotal diameters and testicular volumes in both Kivircik and Charollais rams. Furthermore, melatonin implantation improved the reproductive performances of ewes naturally mated with these melatonin implanted rams during non-breeding season.
\end{abstract}

Keywords: ram, melatonin, fertility, non-breeding season

\section{RESUMO}

Esse estudo foi conduzido para investigar os efeitos de implantação de melatonina em características testiculares básicas e desempenho reprodutivo de carneiros Kivircik e Charollais durante a estação não reprodutiva. Nesse estudo, oito carneiros Kivircik e 6 Charollais foram utilizados. Foi implantado $54 \mathrm{mg}$ de melatonina nos cordeiros de acordo com as instruções do produtor. Ao implantar a melatonina e à introdução do carneiro, foram avaliados o desempenho reprodutivo e as características testiculares. Ao longo do período experimenta, os cordeiros foram mantidos em ambiente externo sob condições de luz e ritmo circadiano naturais e à temperatura ambiente. $O$ efeito de tratamento com melatonina exógena no desempenho reprodutivo de carneiros e ovelhas, resposta estral, taxa de prenhez, tamanho de ninhada e taxa de gemelaridade foram avaliados em todos os grupos. Valores de libido foram significativamente maiores em Charollais comparados a Kivircik $(P<0.001)$. Volume testicular (VT) estava aumentado em ambas as raças. Comprimento escrotal $(C E)$ também estava aumentado tanto em Kivircik quanto em Charollais $(P<0.01)$. Conclui-se que o tratamento de carneiros com implantes de liberação lenta de melatonina aumentou diâmetro e volume testiculares tanto em carneiros Kivircik quanto em Charollais. Ademais, implantação de melatonina melhorou o desempenho reprodutivo de ovelhas naturalmente cruzadas com esses carneiros implantados com melatonina durante o período não reprodutivo.

Palavras-chave: carneiro, melatonina, fertilidade, estação não reprodutiva

Recebido em 14 de julho de 2016

Aceito em 19 de julho de 2016

E-mail: cevikm@omu.edu.tr 


\section{INTRODUCTION}

The fertility of rams indicates a complex relationship between the development of the neuroendocrine system, testosterone concentration, development of individual body parts and sexual maturation (Maksimovic et al., 2016. Seasonal changes in testicular dimensions, preceded by the decrease of luteinizing hormone and the increase of follicle stimulating hormone secretion, have been described in numerous sheep breeds, including the Suffolk, Texel, Dorset, Il-de-France, British Milk Sheep, Serres Finn and Scottish Blackface breeds (Mandiki et al., 1998; Sarlos et al., 2013). Sperm production is correlated to testicular measurements. Scrotal circumference will vary with season and body weight, but should be at its maximum peak during the fall breeding season (Egerszegi et al., 2014; Faigl et al., 2009; Palacin et al., 2008).

Melatonin, synthesised by the pineal gland, is the chemical messenger which allows seasonal animals to perceive day length changes (Chemineau et al., 2008; Mandiki et al. 1998). The exogenous photoperiodic signal is translated through a neuroendocrine pathway to the daily alteration of melatonin level. Exogenous administration of melatonin by slow-release implants may be a reliable method for controlling reproductive rhythm (Rosa et al., 2012; Sarlos et al., 2013). Melatonin can be used alone, or combined with other hormonal treatments, after an artificial light treatment. Treatment with melatonin during non-breeding season can revert the 'long-day effect' over the ram (Faigl et al., 2009; Rosa et al., 2012; Zuniga et al., 2002). In mature rams, the insertion of melatonin implants facilitated testicular growth with an elevated testicular size, sexual behaviour and improved semen characteristics in different breeds (Casao et al., 2010; Chemineau et al., 1996; Egerszegi et al., 2014). The treatment of rams with melatonin between the middle and the end of spring accelerated the seasonal increase in $\mathrm{LH}$ and testicle size and increased the proportion of ewes that ovulated in response to the introduction of a ram (Palacin et al., 2008). Several studies by our group have demonstrated that melatonin treatment increased scrotal diameter in rams and improved reproductive performance of estrus synchronized ewes naturally mated with these melatonin implanted rams during non-breeding season (Casao et al.,
2010; de Nicolo et al., 2008; Palacin et al., 2008). The reproductive seasonality of rams is less expressed as compared to ewes, although melatonin has been shown to influence several parameters of reproductive activity in rams as well. To maximize the efficiency of production in commercial sheep flocks during the nonbreeding season, the production of good quality sperm is fundamental importance, especially in systems where AI is used. Therefore, the objective of this study was to determine whether melatonin implants have a significant effect on reproductive performance and some testicular parameters of Kivircik and Charollais rams during the non-breeding season.

\section{MATERIALS AND METHODS}

This study was conducted on Kivircik and Charollais rams, located at CatalzeytinKastamonu, Turkey (longitude 41 ${ }^{\circ} 52^{\prime} 35.14^{\prime \prime}$ North, latitude $34^{\circ} 13^{\prime} 13.07^{\prime \prime E a s t)}$ and was carried out between April and July, when the daylight length increases. The experiments were carried out according to guidelines for animal research from the National Institutes of Health and all procedures on animals were approved by the Ondokuz Mayis University Ethic Committee on Animal Research in current study (approval date/number: December 2013/ 04-103). In this study, clinically healthy, 8 Kivircik and 6 Charollais rams and with seasonally in anestrus Kivircik $(\mathrm{n}=77)$ and Charollais $(\mathrm{n}=33)$ ewes were subjected to the melatonin treatment. Experiments were performed in non-breeding season under a natural photoperiod environment. Water and mineral licks were offered ad libitum. Prior to the study period, rams were separated from the flock. The body condition scores ranged from 3.0-4.0 with an average of $3.5 \pm 0.4$ (using a scale of 1-5; 1 (emaciated) to 5 (obese)) (Ucar et al., 2005).

Each of the reguline implants contained $18 \mathrm{mg}$ melatonin was placed subcutaneously in the ears. On 09 April (day 0), rams were implanted with $54 \mathrm{mg}$ melatonin (3 pieces of Reguline implant, CEVA - Animal Health, Istanbul, Turkey) according to the manufacturer's instructions, near the base of the ear with a reguline applicator gun. The ewes were isolated from the rams at least one month prior to melatonin implantation. On 17 April, ewes were implanted with $18 \mathrm{mg}$ melatonin (1 pieces of Reguline implant). The 
melatonin implants were not removed. Reguline implant is a long-acting, slow-release device resulting in elevated plasma melatonin levels lasting for approximately 3 months. At melatonin implantation (0 day) and at ram introduction (42 days) the reproductive performance and testicular characteristics of rams were evaluated. Throughout the experimental period, rams were permanently kept outdoors under conditions of natural day length and at ambient temperature. The animals were checked for integrity of their sexual organs prior to the experiment, and they were vaccinated against enterotoxaemia and received oxfendazol (5mg/kg body weight) against internal parasites.

In this study, 8 Kivircik and 6 Charollais rams with known fertility (according to farm records) were used to receive sexual performance and andrological data. To obtain an objective measurement of the effects of the melatonin implants on reproductive performance of rams, we evaluated of the libido sexualis, mounting performance, anogenital sniffing, tail raising and matings, and changes of testicular characteristics. Measurements of testes diameter (TD), scrotal length (SL), scrotal circumference (SC) and testes volume (TV) have been assessed at melatonin implantation ( 0 day) and at ram introduction (42 days). TD $(\mathrm{cm})( \pm 1 \mathrm{~mm})$ was measured with a caliper on the left and right testicles as the widest anteroposterior diameter. $\mathrm{SL}(\mathrm{cm})( \pm 1 \mathrm{~mm})$ was measured with a caliper as the distance between the tip of the scrotal sack and its neck. SC $(\mathrm{cm})$ measurement was obtained while the ram was in a standing position and by pushing the testicles to the bottom of the scrotum, then measuring the greatest circumference with a flexible metal tape. SC was assessed with a measuring tape $( \pm 1 \mathrm{~mm})$ at the maximum anterio-posterior level of the scrotum with the ram in a standing position. Testes volume was measured by the water displacement method.

Six weeks after the implantation of melatonin, rams were ordered in a random sequence within treatment and exposed to ewe in estrus for a 20 min period in a test pen of 5-6 $\mathrm{m}^{2}$. The test facility was constructed to eliminate outside distractions and to prohibit the ram being tested from seeing any ewe other than the teaser ewe. Each ram was evaluated individually by exposing it to estrus ewes for $20 \mathrm{~min}$. Two rams were tested simultaneously while the remaining rams were kept about 20 min away with visual barriers between them and the test pens. Observations were recorded for each ram throughout the $20 \mathrm{~min}$ period. Collected observations were evaluated according to the Kridli et al., (2006) and included anogenital sniffing, mounts, frequency of raising the fat tail of ewes, and mating frequency. Libido was assessed by observing displays of sexual behavior and recording the number and type of responses each ram exhibited toward the ewes. To evaluate the effects of exogenous melatonin treatments to rams on the reproductive performances of ewes, estrus response (percentage of ewes in estrus), pregnancy rate (number of pregnant ewes / total number of ewes), litter size (number of lambs born / total number of ewes), and twinning rate were evaluated in all groups. The pregnancy rate, litter size and twinning rate were recorded at parturition.

In this study, the data are summarized by descriptive statistics in terms of mean and their standard error of means (Mean \pm SE). Andrological traits compared by breed were performed with the standard Chi-Square and Fisher's exact test. All analysis and statistical calculation were executed by SAS (2009). Data for all other traits were transformed to logarithms before analysis. Contrasts were used to compare group means when the main or interaction effects were significant, $(\mathrm{P}<0.05)$.

\section{RESULTS}

Overall mean values of some sexual performance parameters in melatonin treated rams during the non-breeding season are presented in Table 1 . The pre-copulatory and copulatory sexual behaviour (anogenital sniffing, tail rising e.g.) was not significantly differed among the groups $(\mathrm{P}>0.05)$. Charollais rams, however, had greater $(\mathrm{P}<0.05) \quad$ tail-raising frequency, mounting efficiency (number of mounts / tail-raising) and greater mating rate than Kivircik rams. In all of the melatonin implanted rams, especially in Charollais rams, aggressive behaviour towards females (head butting e.g.) was observed. Mounting efficiency improved $(\mathrm{P}<0.05)$ with melatonin implantation in Charollais rams compared to Kivircik rams. Regarding libido sexualis, melatonin treated Charollais rams 
exhibited significantly higher libido $(5.0 \pm 0.28)$ compared to Kivircik rams $(4.0 \pm 0.28)(\mathrm{P}<0.001)$. The testicular characteristics of both ram breeds during and after 42 days of melatonin treatment are presented in Table 2. Significant differences were seen in values between the first melatonin implantation and 42 days later regarding the scrotal dimensions. During this period, the SL of Kivircik rams increased from $12.6 \pm 0.95$ to $14.1 \pm 0.40 \mathrm{~cm}$ (NS) and from $19.4 \pm 0.85$ to $22.8 \pm 0.75 \mathrm{~cm}(\mathrm{P}<0.01)$ for the Charollais rams. The increase in SC was more marked in the Charollais $(\mathrm{P}<0.01)$ than in the Kivircik rams (NS). Both breeds showed increases in TD but the differences were not significant. There was a large increase in TV for both Kivircik (442 \pm 14.0 vs. $\left.639 \pm 41.5 \mathrm{~cm}^{3} ; \mathrm{P}<0.01\right)$ and Charollais rams $\left(650 \pm 140\right.$ vs. $\left.1075 \pm 225 \mathrm{~cm}^{3} ; \mathrm{P}<0.001\right)$. Scrotal length, SC, TD and TV were smaller for Kivircik than Charollais rams both during and after melatonin treatment. The breed differences were significant $(\mathrm{P}<0.05$ and $\mathrm{P}<0.001)$ except for $\mathrm{TD}$. For example, TD for Charollais was approximately 1.5 times that of Kivircik after 45 $\mathrm{d}$ of treatment $(9.20 \pm 0.15$ versus $6.05 \pm 0.15)$. The difference was not statistically significant but it was large and the trend was similar for all the other varieties. Fertility rates, which mated with the melatonin-treated rams increased significantly in both the Kivircik and Charollais ewes at the non-breeding season. estrus response for the melatonin treated ewes was $0.97 \pm 0.16$ for Kivircik and $1.00 \pm 0.00$ for Charollais and differences between breeds were not significant $(\mathrm{P}>0.05) \quad$ (Table 3). A similar pattern was observed for the degree of estrus response. Pregnancy rate was $0.92 \pm 0.26$ for the Kivircik and $1.30 \pm 1.74$ for the Charollais ewes treated with melatonin $(\mathrm{P}<0.05)$. When the breeds were analysed separately, melatonin treatment increased the fertility rate significantly in both the Kivircik and Charollais ewes $(\mathrm{P}<0.05)$. The twinning rate was significantly lower for melatonin treated Kivircik than Charollais ewes $(0.44 \pm 0.01$ vs. $0.60 \pm 0.06 ; \mathrm{P}<0.05)$. Charollais and Kivircik ewes mated to rams that received melatonin implants produced $1.48 \pm 0.66$ and $1.32 \pm 0.65$ lambs born per ewe, respectively. Charollais ewes mated with melatonin-treated rams had significantly $(\mathrm{P}<0.05)$ higher lambing rates compared to Kivircik ewes.

Table 1. Sexual performance values in melatonin treated different breed rams during the non-breeding season

\begin{tabular}{lcccc}
\hline \multicolumn{1}{c}{ Parameters } & $\begin{array}{c}\text { Charollais } \\
(\mathrm{n}=6)\end{array}$ & $\begin{array}{c}\text { Kivircik } \\
(\mathrm{n}=8)\end{array}$ & P-value & Significance \\
\hline Libido sexualis (was scored 1-5) & $50.0 \pm 0.28 \mathrm{a}$ & $4.0 \pm 0.28 \mathrm{~b}$ & 0.001 & $*$ \\
Mounts (no./20 min) & $10.0 \pm 0.50 \mathrm{a}$ & $8.6 \pm 1.00 \mathrm{~b}$ & 0.013 & $*$ \\
Anogenital sniffing (no./20 min) & $10.8 \pm 1.30$ & $9.9 \pm 1.30$ & 0.348 & $\mathrm{NS}$ \\
Tail rising (no./20 min) & $3.50 \pm 0.50 \mathrm{a}$ & $1.0 \pm 0.5 \mathrm{~b}$ & 0.042 & $*$ \\
Matings (no./20 min) & $0.40 \pm 0.10 \mathrm{c}$ & $0.1 \pm 0.1 \mathrm{~d}$ & 0.01 & $*$ \\
\hline
\end{tabular}

Explanation: Sexual performance testing was performed during the melatonin implantation and on 42-45 days after implantation.

${ }^{\mathrm{ab}}$ Means (Mean $\pm \mathrm{SE}$ ) within the same row with different superscript letters differ significantly $(\mathrm{P}<0.05$ and $\mathrm{P}<0.001$ ).

${ }^{\mathrm{cd}}$ Means within the same row with different superscript letters differ at $(\mathrm{P}<0.01)$.

Table 2. The testicular measurements in melatonin treated different breed rams during the non-breeding season

\begin{tabular}{|c|c|c|c|c|c|c|c|}
\hline \multirow{2}{*}{ Parameters } & \multirow{2}{*}{ Measurement time } & \multicolumn{3}{|c|}{ Charollais } & \multicolumn{3}{|c|}{ Kivircik } \\
\hline & & Mean \pm SE & $\mathrm{P}$-value & Sign. & Mean \pm SE & P-value & Sign. \\
\hline \multirow{2}{*}{ Scrotal length $(\mathrm{cm})$} & 1 & $19.35 \pm 0.85$ & & & $12.55 \pm 0.95$ & & \\
\hline & 2 & $22.75 \pm 0.75$ & 0.01 & * & $14.10 \pm 0.40$ & 0.21 & NS \\
\hline \multirow{2}{*}{ Scrotal circumference $(\mathrm{cm})$} & 1 & $34.95 \pm 2.55$ & & & $30.95 \pm 0.75$ & & \\
\hline & 2 & $40.00 \pm 3.70$ & 0.01 & $*$ & $32.10 \pm 0.90$ & 0.08 & NS \\
\hline \multirow{2}{*}{ Testicle Diameter (cm) } & 1 & $8.47 \pm 0.22$ & & & $5.60 \pm 0.10$ & & \\
\hline & 2 & $9.20 \pm 0.15$ & 0.06 & NS & $6.05 \pm 0.15$ & 0.07 & NS \\
\hline \multirow{2}{*}{ Testicle volume $\left(\mathrm{cm}^{3}\right)$} & 1 & $650.0 \pm 140.0$ & 0.001 & $* *$ & $442.00 \pm 14.00$ & & \\
\hline & 2 & $1075.0 \pm 225.0$ & & & $638.50 \pm 41.50$ & 0.01 & $*$ \\
\hline
\end{tabular}

Scrotal and testicular measurements were performed during the melatonin implantation ${ }^{(1)}$ and on $42-45$ days after implantation ${ }^{(2)}$.

Means $( \pm$ SEM) having different superscripts within the same row are significantly different from each other.

$*: \mathrm{P}<0.05$; **: $\mathrm{P}<0.01$; NS: not significant $(\mathrm{P}>0.05)$. 
Table 3. The reproductive performance of ewes mated with melatonin implanted rams during nonbreeding season

\begin{tabular}{lccc}
\hline \multirow{2}{*}{ Variables } & \multicolumn{3}{c}{ Treatments } \\
\cline { 2 - 4 } & $\begin{array}{c}\text { Charollais } \\
(\mathrm{n}=33)\end{array}$ & $\begin{array}{c}\text { Kivircik } \\
(\mathrm{n}=77)\end{array}$ & $\mathrm{P}$-value \\
\hline Estrus response & $1.00 \pm 0.00$ & $0.97 \pm 0.16$ & $\mathrm{P}>0.05$ \\
Pregnancy Rate & $1.30 \pm 1.74 \mathrm{a}$ & $0.92 \pm 0.26 \mathrm{~b}$ & $\mathrm{P}<0.05$ \\
Twining Rate & $0.60 \pm 0.06 \mathrm{a}$ & $0.44 \pm 0.01 \mathrm{~b}$ & $\mathrm{P}<0.05$ \\
Litter size & $1.48 \pm 0.66$ & $1.32 \pm 0.65$ & $\mathrm{P}>0.05$ \\
\hline${ }^{\mathrm{ab}}$ Means (Mean \pm SEM) within the same row with different superscript letters differ significantly $(\mathrm{P}<0.05)$.
\end{tabular}

\section{DISCUSSION}

In the present study we investigated the effects of melatonin treatment on the sexual performance and testicular characteristics of Kivircik and Charollais rams at the non-breeding season. Exogenous melatonin implants in rams improved the net lamb production of ewes under field conditions, and significantly so in the Charollais breed. Fertility values, which mated with the melatonin-treated rams has increased significantly in both ewes. According to andrological values from the study, melatonin implantation in the non-breeding season significantly improved scrotal circumference and testicular volume of all rams, and also led to significant improvements in reproductive performance. Andrological evaluations are important in management practice, especially for artificial insemination in a breeding program. Genetic improvements of sheep rely on the intensive use of a few superior rams either for natural mating or in artificial insemination programs. Seasonal changes are less marked in rams than in ewes because spermatogenesis and sexual activity never stop, while females have a definite anestrus period (Casao et al., 2010; Endale et al., 2009; Palacin et al., 2008; Rosa et al., 2012). It is well known that sexual performance of rams is highly variable. Libido can be quantified in male farm animals by measuring their motivation to seek out and the frequency with which they engage in precopulatory and copulatory behaviors with mating partners (Price et al., 1991). Libido testing measures are the sexual urge or sexual desire of the ram. It is not a measure of fertility or mating ability (Perkins et al., 1992; Price et al., 1991).

The success of such breeding programs highly depends on reproductive performance of rams. There are many factors that affect sex drive and sexual performance. These factors include: season of year, genetics, breed differences, hormonal influence, post-weaning management, temperature and nutrition (Kridli et al., 2006, 2007; Mandiki et al., 1998; Palacin et al., 2008; Rosa et al., 2012). Pre-copulatory behaviour in rams reflects their underlying sexual motivation. This means that the higher the frequency of precopulatory behaviour, the greater the frequency of other sexual activities (mounting and mating) (Egerszegi et al., 2014; Kridli et al., 2006; Sarlos et al., 2013). According to the study results, most sexual performance parameters were better in Charollais compared with the Kivircik males. Charollais rams $(5.0 \pm 0.28)$ had greater libido sexualis than Kivircik rams $(4.0 \pm 0.28)(\mathrm{P}<$ 0.001). Aggressive behaviour towards females (head butting) was observed in two breeds. Mounting efficiency improved with ram introduction, especially in Charollais rams $(\mathrm{P}<$ 0.05) compared with other group rams. According to Kridli et al., (2007), puberty in rams begins with increased libido and the production of sperm cells having the capacity of fertilization. Each gram of testicle produces about $20 \times 10^{6}$ sperm cells per day, irrespective of size. Scrotal circumference is a good index of sperm production in the ram. Therefore, scrotal circumference and testicular diameter are suitable traits as selection criteria to improve reproductive performance. They are also traits that can easily be measured in live animals (Endale et al., 2009). It is well known that testicular size as well as efficiency of spermatogenesis of rams are at their top levels during the breeding season and decrease during the non-breeding season. Seasonal changes in testicular dimensions, preceded by the decrease of LH and the increase of FSH secretion, have been described in numerous sheep breeds, including the Suffolk, Texel, Dorset, Il-deFrance, British Milk Sheep, Soay, Karakul, Chios, Serres Finn and Scottish Blackface breeds 
(Sarlos et al., 2013; Mandiki et al., 1998). In British Milk rams, testicular volume was the lowest in winter, then after a continuous increase it reached the highest value in autumn. The maximal testicle mass measured in September exceeded the lowest value found in January by $33.5 \%$ (Sarlos et al., 2013).

Palacin et al. (2008) reported that melatonin treatment increased scrotal diameter in rams and improved reproductive performance of estrus synchronized ewes naturally mated with these melatonin implanted rams during non-breeding season. In the present study, SL and SC were also higher in melatonin implanted Charollais rams compared to Kivircik rams $(\mathrm{P}<0.05)$. Although TD increased significantly in both Kivircik and Charollais rams, their size did not significantly differ between both breeds. In this study, the changes of SC and TD dimensions in Kivircik rams were similar to that reported by Egerszegi et al. (2014); Endale et al. (2009) and Rosa et al. (2012). Whereas SL and TD dimensions in the melatonin-treated Charollais rams were higher than that by Kridli et al. (2007); Kridli et al. (2006) and Egerszegi et al. (2014). The differences in the testes measurements might be due to breed, age, feeding and season. Testicular volume measurement is a significant criterion in spermatogenesis prediction and evaluating testicle functions in humans. Because testicle volume is composed of tubuli seminiferi contorti and tubuli seminiferi recti, any change in testis measurements reflects the changes in this tissue mass and also spermatogenesis (Casao et al., 2010; Kridli et al., 2007). We have established that the testicular volume was substantially influenced by the melatonin administration out of the breeding season. Significant differences were seen in values between the first melatonin implantation and recorded 42 days later between the breeds. The testicular volume values were higher than that reported by Rosa et al. (2012) and Endale et al. (2009). Rosa et al. (2012) reported the same trend for SC in Charollais and Texel rams without any significant difference. In agreement with our findings, others (Faigl et al., 2009; Palacin et al., 2008) found that the testicular weight of the implanted animals increased 2-3 weeks after the onset of melatonin treatment and reached its maximum 5 weeks later. Palacin et al. (2008) reported that melatonin treatments during the non-breeding period can increase testicular growth. Significant differences were seen in seasonal scrotal circumference values between spring-winter, spring-summer, spring-autumn, summer-winter, summer-autumn and autumn-winter (Sarlos et al., 2013). Similarly, we have established that testicular dimensions were substantially influenced by the season. Palacin et al. (2008) reported that, melatonin treatment increased scrotal diameter in rams and improved reproductive performance of estrus synchronized ewes with these melatonin implanted rams during non-breeding season. In agreement with our findings, Fitzgerald and Stellflug (1991) found that the fertility of ewes mated with melatonin treated rams (99\%) was significantly higher than the fertility of ewes mated to control males $(75 \%)$. That increase in the lambing rate after rams were treated with melatonin was greater than the rate observed when only ewes received melatonin implants in the same conditions reported by Forcada et al. (2002) (80\% vs. $77 \%$ ) and Horoz and Kaşikci (2003) (95\% vs. $75 \%)$.

In conclusion, we showed that the treatment of rams with slow release implants of melatonin increased scrotal diameter and testicular volume and improved the reproductive performance of estrus synchronized ewes naturally mated with these melatonin implanted rams during nonbreeding season. Further research involving the study of semen quality has been planned to confirm such results and to investigate the physiological mechanisms involved in these observations, which might differ among breeds.

\section{REFERENCES}

CASAO, A.; VEGA, S.; PALACIN, I. et al. Effects of melatonin implants during non-breeding season on sperm motility and reproductive parameters in Rasa Aragonesa rams. Reprod. Dom. Anim., v.45, p.425432,2010

CHEMINEAU, P.; BELTRAN, I.; DAVEAU, A.; BODIN, L. High repeatability of the amplitude and duration of the nycthemeral rhythm of the plasma melatonin concentration in the Ile-de-France ewe. $J$. Pineal Res., v.21, p.1-6, 1996.

CHEMINEAU, P.; GUILlaUME, D.; MIGAUD, M. et al. Seasonality of reproduction in mammals: intimate regulatory mechanisms and practical implications. Reprod. Dom. Anim., v.43, p.40-47, 2008. 
EGERSZEGI, I.; SARLOS, P.; RATKY, J. et al. Effect of melatonin treatment on semen parameters and endocrine function in Black Racka rams out of the breeding season. Small Ruminant Res., v.116, p.192198, 2014.

ENDALE, M.; HAİLEMARİAM, M.; TEGEGNE, A. A study on testicular characteristics of ram lambs of Arsi breed fed on two maize varieties. Ethiopian $J$. Sci., v.32, p.37-44, 2009.

FAIGL, V.; KERESZTES, M.; KULCSAR, M. et al. Testicular function and semen characteristics of Awassi rams treated with melatonin out of the breeding season. Acta Vet. Hung., v.57, p.531-540, 2009.

FITZGERALD, J.A.; STELLFLUG, J.N. Effects of melatonin on seasonal changes in reproduction of rams. J. Anim. Sci., v.69, p.264-275, 1991.

FORCADA, F.; ZUNIGA, O.; ABECIA, J.A. The role of nutrition in the regulation of LH secretion during anoestrus by the serotoninergic and dopaminergic systems in Mediterranean ewes treated with melatonin. Theriogenology, v.58, p.1303-1313, 2002.

HOROZ, H.; KASIKCI, G. Controlling the breeding season using melatonin and progestagen in Kivircik ewes. Turk. J. Vet. Anim. Sci., v.27, p.301-305, 2003.

KRIDLI, R.T.; ABDULLAH, A.Y.; SHAKER, M.M Sexual performance and reproductive characteristics of young adult Awassi, Charollais-Awassi and Romanov-Awassi rams. Sheep Goat Res. J., v.21, p.12-16, 2006.

KRIDLI, R.T.; MOMANY SHAKER, M. et al. Sexual behaviour of yearling Awassi, Charollais x Awassi and Romanov $\mathrm{x}$ Awassi rams exposed to oestrus Awassi ewes. Trop. Anim. Health Prod., v.39, p.229235, 2007.

MAKSIMOVIC, N.; HRISTOV, S.; STANKOVIC, B. et al. Investigation of serum testosterone level, scrotal circumference, body mass, semen characteristics and their correlations in developing MIS lambs. Turk. J. Vet. Anim. Sci., v.40, p.53-59, 2016.
MANDIKI, S.N.M.; DERYCKE, G.; BISTER, J.L.; PAQUAY, R. Influence of season and age on sexual maturation parameters of Texel, Suffolk and Ile-deFrance rams. 1. Testicular size, semen quality and reproductive capacity. Small Ruminant Res., v.28, p.67-79, 1998 .

NICOLO, G.; MORRIS, S.T.; KENYON, P.R. et al. Melatonin-improved reproductive performance in sheep bred out of season. Anim. Reprod. Sci., v.109, p.124-133, 2008.

PALACIN, I.; ABECIA, J.A.; FORCADA, F. et al. Effects of exogenous melatonin treatment on out-ofseason ram fertility. Ital. J. Anim. Sci., v.7, p.199-206, 2008.

PERKINS, A.; FITZGERALD, J.A.; PRICE, E.O. Sexual performance of rams in serving capacity tests predicts success in pen breeding. J. Anim. Sci., v.70, p.2722-2725, 1992.

PRICE, E.O.; ESTEP， D.Q.; WALLACH， S.J.; DALLY, M.R. Sexual performance of rams as determined by maturation and sexual experience. $J$. Anim. Sci., v.69, p.1047-1052, 1991.

ROSA, H.J.D.; SILVA, C.C.; BRYANT, M.J. The effect of melatonin treatment in rams on seasonal variation of testicular size and semen production parameters. Small Ruminant Res., v.102, p.197-201, 2012.

SARLOS, P.; EGERSZEGI, I.; BALOGH, O. et al. Seasonal changes of scrotal circumference, blood plasma testosterone concentration and semen characteristics in Racka rams. Small Ruminant Res., v.111, p.90-95, 2013.

SAS user guide, version 9.01. Cary: SAS, 2009.

UCAR, O.; KAYA, M.; YILDIZ, S. et al. Effect of progestagen/PMSG treatment for oestrus synchronization of Tuj ewes to be bred after the natural breeding season. Acta Vet. Brno, v.74, p.385393, 2005.

ZUNIGA, O.; FORCADA, F.; ABECIA, J.A. The effect of melatonin implants on the response to the male effect and on the subsequent cyclicity of Rasa Aragonesa ewes implanted in April. Anim. Reprod. Sci., v.72, p.165-174, 2002. 